\title{
Social accountability: What are the lessons for improving family planning and reproductive health programs?
}

Victoria Boydell

Jill Keesbury

Follow this and additional works at: https://knowledgecommons.popcouncil.org/departments_sbsr-rh

Part of the Demography, Population, and Ecology Commons, Family, Life Course, and Society Commons, International Public Health Commons, and the Sociology of Culture Commons How does access to this work benefit you? Let us know!

\section{Recommended Citation}

Boydell, Victoria and Jill Keesbury. 2014. "Social accountability: What are the lessons for improving family planning and reproductive health programs?" Working paper. Washington, DC: Population Council, Evidence Project. 


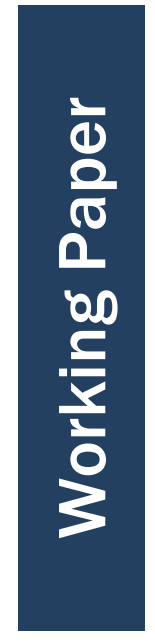

\section{Social Accountability: What are the Lessons for Improving Family Planning and Reproductive Health Programs?}

A Review of the Literature

Victoria Boydell and Jill Keesbury

October 2014 


\section{The Evidence Project}

Population Council

4301 Connecticut Avenue, NW, Suite 280

Washington, DC 20008 USA

Tel : +1 2022379400

Email : evidenceproject@popcouncil.org

evidenceproject.popcouncil.org

(-) USAID

The Evidence Project is made possible by the generous support of the American people through the United States Agency for International Development (USAID) under the terms of cooperative agreement no.

AID-OAA-A-13-00087. The contents of this document are the sole responsibility of the Evidence Project and Population Council and do not necessarily reflect the views of USAID or the United States Government.

\section{Evidence}

The Evidence Project uses implementation science- the strategic generation, translation, and use of evidence - to strengthen and scale up

family planning and reproductive health programs to reduce unintended pregnancies worldwide. The Evidence Project is led by the Population Council in partnership with INDEPTH Network, International Planned Parenthood Federation, Management Sciences for Health, PATH, Population Reference Bureau, and the project's University Resource Network.

Published in October 2014

Suggested citation: Boydell, Victoria and Jill Keesbury. 2014. "Social Accountability: What are the Lessons for Improving Family Planning and Reproductive Health Programs? A Review of the Literature," Working Paper. Washington, DC: Population Council, Evidence Project.

C 2014 The Population Council, Inc. 



\section{Table of Contents}

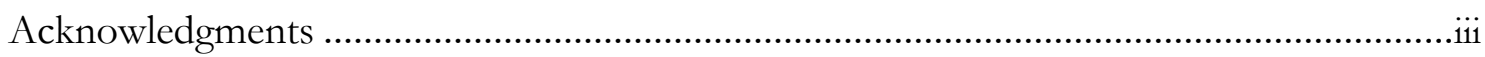

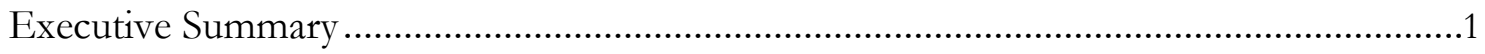

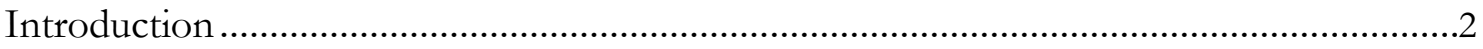

Methodology and Search Strategy .............................................................................

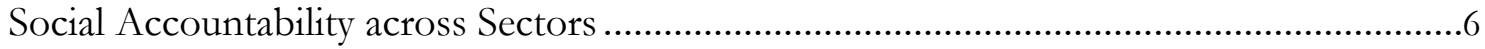

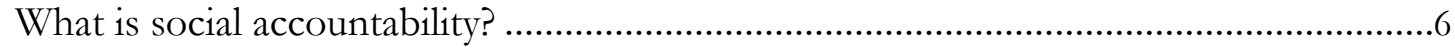

What is the evidence on effectiveness and impact? .....................................................10

What are important elements of social accountability interventions?............................11

Social Accountability in the FP/RH Sector....................................................................14

What is 'social accountability' in the FP/RH sector? ..................................................14

What is the evidence on effectiveness and impact? .......................................................16

Do FP/RH interventions include the important elements of social accountability? .....17

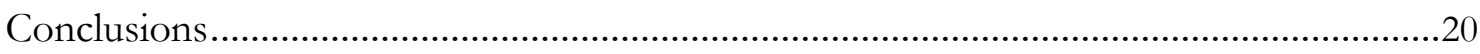

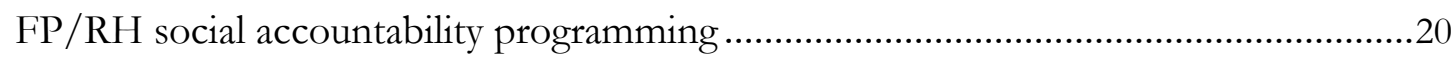

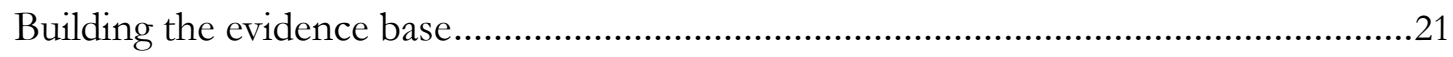

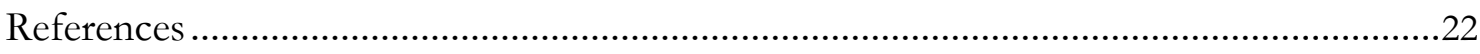

Appendix 1: Types of Social Accountability Interventions ............................................29

Appendix 2: Overview of the Enabling Factors for Successful Social Accountability .......31

Appendix 3: Social Accountability Interventions in FP/RH Programming ......................33 


\section{Acknowledgments}

This working paper was written by Victoria Boydell of the Evidence Project/International Planned Parenthood Federation and Jill Keesbury of the Evidence Project/PATH. It was prepared for the July 16-17, 2014 experts meeting, "Strengthening the Evidence Base on Social Accountability for Improving Family Planning and Reproductive Health Programs" and subsequently revised. The expert consultation was convened by the Evidence Project and the International Planned Parenthood Foundation in London.

Both the paper and experts meeting are part of a larger initiative of the Evidence Project to strengthen the evidence on whether, and how, implementation of social accountability mechanisms in FP/RH programs improves access to, and quality of, services. More information, including the meeting report, can be found at evidenceproject.popcouncil.org.

The authors extend their thanks to the following colleagues of the Evidence Project for their valuable contributions: Karen Hardee for her thoughtful and thorough technical review of the paper, Ellen Weiss for technical and editorial support, Kelsey Wright for additional content, Catherine Unthank for finalizing the document, and Kay Wilson for the search of the literature. 



\section{Executive Summary}

The concept of accountability is increasingly important in the family planning (FP) and reproductive health $(\mathrm{RH})$ field. While much recent discussion has focused on developing global or national-level mechanisms for accountability, less emphasis has been placed on understanding the relevance of 'social accountability' approaches for ensuring access to, and the quality of, FP/RH services. Social accountability refers to the efforts of citizens and civil society to scrutinize and hold duty bearers (politicians, government officials, and service providers) to account for providing promised services, actions most often at the sub-national or community level. In the FP/RH field, this concept builds on a rich history of community involvement and civil society participation.

This paper draws on the debates and emerging lessons of the social accountability field to better understand its potential for improving $\mathrm{FP} / \mathrm{RH}$ programs. It synthesizes the literature across a variety of sectors including the health sector, and on broad review papers as well as individual studies related to $\mathrm{FP} / \mathrm{RH}$ programs.

Overall, it finds the field of social accountability to be a dynamic one, with a variety of initiatives and interventions across different levels and contexts. It identifies nine different types of social accountability interventions employed in a variety of settings, but notes that the evidence base on their effectiveness and impact remains weak. Despite these gaps, the literature indicates a growing consensus on the important elements of these activities, stressing the need for a clearly articulated theory of change, an understanding of how context affects such socially-embedded interventions, clear linkages to redress and remedy mechanisms, and the presence of a set of core environmental factors that enable the implementation of such complex interventions.

Looking specifically at the $\mathrm{FP} / \mathrm{RH}$ literature, the types of social accountability interventions most frequently applied focused on some form of community monitoring of health facilities. While these types of interventions were shown to have great potential for increasing FP/RH service quality and access, questions remain about how and when social accountability interventions can best be employed. One important question is how to maintain a client's right to privacy while implementing a social accountability initiative within the public sphere. As with the general literature on social accountability, however, evidence of program impact or effectiveness is generally limited. Yet, the picture of social accountability initiatives in the literature is most likely incomplete, as the published evidence does not capture the range of activities in the field.

This review concludes that in order to build the evidence base on what works in the FP/RH field, it may be expedient to focus on those social accountability interventions with some track record in achieving positive outcomes. Such interventions could benefit from an implementation science approach that examines not only outcomes, but the strengths and shortcomings of their actual implementation. 


\section{Introduction}

Over the last decade, the concept of accountability has received increased attention in the development dialogue, particularly regarding aid effectiveness. At its most basic, accountability entails:
...the duty to provide an account (by no means necessarily a financial account) or reckoning of those actions for which one is held responsible. This accountability involves two responsibilities or duties: the responsibility to undertake certain actions (or forebear from taking these actions), and the responsibility to account for those actions (Cronin and O'Regan 2002, p. viii).

Many have argued that limited effectiveness of state accountability has undermined the achievement of development goals (McGee and Gaventa 2011; World Development Report 2004; Ringold et al. 2012). This is especially important in an era of scarce resources and austerity measures in donor countries. A key donor in the field, the United Kingdom's Department for International Development (DFID), has explicitly recognized the link between accountability and impact, stating, "in order to make every penny count and increase the reach of development initiatives, we have to ensure that officials are accountable for their commitments and the poorest people are able to access available opportunities, resources and services" (Department for International Development 2011, p.1).

Building on a history of community participation in family planning and a focus on civil society participation in partnership with governments that grew out of the 1994 International Conference on Population and Development (ICPD), the concept of accountability is important in the family planning (FP) and reproductive health (RH) fields. It is a central pillar of the FP2020 movement, which aims to galvanize the global community around the goal of reaching an additional 120 million women and girls with contraceptive information and services by 2020. To support this goal, both donor and aid recipient governments have made ambitious commitments to improve access to FP in 69 focus countries in Africa and Asia. The FP2020 movement is now grappling with strategies to ensure commitment-makers are held to account on their public promises and is developing a range of approaches to measure change at both the national and global levels.

Other global initiatives that include FP/RH have also developed accountability measures to track progress against goals, most of which include tracking basic national indicators on service coverage or spending. These include the United Nations Secretary General's Every Women Every Child Initiative, the United Nations Commission on Life-Saving Commodities, and the Ouagadougou Partnership.

Additionally, key global FP/RH frameworks recognize accountability as central to transforming services and meeting unmet need for FP, such as the Conceptual Framework for Voluntary, Human Rightsbased Family Planning and the World Health Organization's Guidance and Recommendations on Ensuring Human Rights in the Provision of Contraceptive Information and Service (Hardee et al. 2014; WHO 2014).

While much discussion in the FP/RH field has focused on developing global or national mechanisms for accountability, less emphasis has been placed on exploring the relevance of 'social accountability' approaches for ensuring accessible and quality FP/RH services. Social accountability refers to the efforts of citizens and civil society to scrutinize and hold duty bearers (politicians, government officials, and service providers) to account for providing promised services, actions that most often take place at the sub-national or community level. Social accountability is premised on the assumption that increased citizen engagement will force public officials to act on their commitments. Social accountability interventions reportedly have the potential for addressing the misuse of public 
funds, issues around staff vacancies, poor infrastructure, and ensuring that resources meet legal requirements, professional standards and societal values (Brinkerhoff 2004). Health policy is increasingly focusing on social accountability as a means for improving quality and increasing uptake of services (Brinkerhoff 2004; George 2007; Murthy and Klugman 2004). While this approach may hold promise for contributing to equitable, rights-based access to quality $\mathrm{FP} / \mathrm{RH}$ services, significant gaps remain in the evidence base on the effectiveness of social accountability in general, and specifically FP/RH.

This paper draws on the debates and emerging lessons of the social accountability field to better understand its potential for improving $\mathrm{FP} / \mathrm{RH}$ programs. It synthesizes the literature across a variety of sectors, including the health sector, for review papers as well as individual studies.

The paper is organized in four sections. The first section presents the methodology used in this literature review. The second section describes the literature on social accountability across different sectors to identify the strengths and shortcomings of current approaches. The third section examines social accountability, specifically for FP/RH, looking both at global trends in FP/RH accountability and specific programming examples. The fourth section offers conclusions on social accountability for FP/RH efforts based on the literature reviewed to date. 


\section{Methodology and Search Strategy}

This synthesis draws on the literature on social accountability broadly and on social accountability related to $\mathrm{FP} / \mathrm{RH}$ programs more specifically. It is informed by a realist review approach, which is useful in understanding the elements of complex interventions such as social accountability. Realist reviews work to develop a theoretical framework for analyzing empirical evidence and are guided by the question "What works for whom in what circumstances and in what respects?" (Pawson et al. 2005). While the process of selecting literature for a realist review follows a set of widely-accepted principles, it is also iterative and dynamic. As such, the search strategies described evolved throughout the search process and additional literature was added as necessary.

To begin the process of identifying and compiling the relevant literature from the peer-reviewed and 'grey' literature, key searchable words were chosen that related to social accountability across different sectors. These terms were entered in a range of different search engines, including PubMed/Medline, POPLINE, ScienceDirect, and the World Wide Web via Google. This literature search strategy also built on an existing review, "Civil Society and Social Accountability," by the USAID-funded Health Policy Project to define and describe tools for social accountability currently used in the field.

This search yielded a total of 2,663 references for initial review. The titles of the documents were then examined, and 658 articles were identified that best matched the aims and focus of this review paper. These 658 references were grouped into five categories, shown in Table 1.

\section{Table 1: Search Terms Related to "Civil Society and Social Accountability" and Number of References Identified}

\begin{tabular}{|l|c|}
\hline Topic & Number of References \\
\hline Family Planning & 271 \\
\hline Reproductive Health (not FP) & 115 \\
\hline Maternal and Child Health (not FP or RH) & 106 \\
\hline Other Health & 81 \\
\hline Other General & 85 \\
\hline
\end{tabular}

From the literature, ${ }^{1}$ we identified 12 review papers from the "Other Health" and "Other General" categories that we included in our analysis: Agarwal et al. 2009; Holland et al. 2009; Joshi 2010; Malena et al. 2004; McGee and Gaventa 2011; Menocal and Sharma 2008; Molyneux 2012; O’Neill et al. 2007; O’Meally 2013; Ringold et al. 2012; Fox 2014; and Hoffman 2014. These reviews were assessed to identify common trends and thinking in social accountability in general that would frame the review of the literature specific to FP/RH. We found one review (Freedman and Schaff, 2013) focused on accountability in the FP/RH sector. In a few instances we went back to the original papers that were cited by the review papers.

The 386 papers categorized as FP or RH (not including FP) were reviewed. They included case studies, toolkits, guidance documents, calls to action, and theoretical frameworks pertaining to social accountability. Of these, 16 case studies were selected for further analysis. In total, this synthesis draws on 13 review papers and $16 \mathrm{FP} / \mathrm{RH}$ case studies.

\footnotetext{
1 Three of the references were identified by participants of the expert meeting and were subsequently added to the analysis in the paper.
} 
This literature was also supplemented with general information on social accountability initiatives in the FP/RH field, all of which reference accountability as a key strategy in achieving their objectives. 


\section{Social Accountability Across Sectors}

In 2010 DFID, as part of the Transparency and Accountability Initiative, ${ }^{2}$ commissioned the Institute of Development Studies to research the impact and effectiveness of social accountability. The study found almost no 'meta-literature' on accountability's impact and effectiveness, and any existing work was variable and scattered. It also concluded that the existing literature was largely theoretical, replete with under-specified assumptions about inputs and outcomes, and with few studies of impact. The chain of causation from increasing citizen awareness to resulting change was difficult to track and measure (McGee and Gaventa 2011).

In the short period since the DFID study's publication, there has been much new work on social accountability. This paper builds on that review and incorporates more recent literature in the field, with specific emphasis on social accountability efforts in the health sector. While there are still important evidence gaps on social accountability, there is general agreement on the factors underpinning successful social accountability efforts. These factors can provide a basis for developing and assessing FP/RH accountability initiatives.

\section{WHAT IS SOCIAL ACCOUNTABILITY?}

Definitions of social accountability vary, yet they all focus on citizens holding actors accountable. They include:

- "The process of holding actors responsible for their actions. More specifically, it is the concept that individuals, agencies and organizations (public, private and civil society) are held responsible for executing their powers according to a certain standard (whether set mutually or not)" (McGee and Gaventa 2011, p. 2).

- "A set of tools that citizens can use to influence the quality of service delivery by holding providers accountable" (Ringold et al. 2012, p. 7).

- "The ability of citizens, civil society and the private sector to scrutinize public institutions and governments and to hold them to account" (Holland et al. 2009, p. 4).

- "Strategies [that] try to improve public sector performance by bolstering both citizen engagement and government responsiveness" (Fox 2014).

Considering these definitions, social accountability can be defined as the efforts of citizens and civil society to collect and scrutinize relevant information and use this information to hold duty bearers (i.e., politicians, government officials, and/or service providers) to account for delivering promised services at the community level. Social accountability interventions aim to strengthen the agency of citizens, both individually and collectively, in holding actors accountable.

This definition implies that the state has a responsibility or obligation to respond in some way to citizen demands. State responses can range from duty bearers answering questions raised (answerability) to sanctions for failing to answer accountability claims (enforcement) (Goetz and

\footnotetext{
2 The Transparency and Accountability Initiative is a donor collaborative working to expand the impact and scale of transparency and accountability interventions. It includes DFID, the Ford Foundation, Hivos, the International Budget Partnership, the Omiday Network, the Open Society Institute, the Revenue Watch Institute, and the William and Flora Hewlett Foundation.
} 
Jenkins 2002). According to Molyneux et al. (2012, p. 542) "responsiveness can be defined as changes made to the health system on the basis of ideas or concerns raised by, or with, community members through formally introduced decision-making mechanisms."

McGee and Gaventa (2011) summarize three typical outcomes from social accountability interventions:

- Democratic outcomes: more informed, organized, and systematic engagement between citizens and the state.

- Developmental outcomes: more effective service delivery and public sector performance.

- Empowerment outcomes: increased or improved means to increase and aggregate the voice of the disengaged and vulnerable groups.

Ringold et al. (2012) highlight the theory of change in reaching these outcomes: "If citizens have access to information about their rights and the type and quality of services that they should expect, and if they have opportunities to use this information to affect the behavior of providers and the decisions of policy makers, they can influence service delivery." They also highlight the key assumptions of this approach, that people are able to and willing to use information about services and that policymakers or providers are responsive to them.

Brinkerhoff (2004) reminds us that although social accountability may seem straightforward, it is highly complex and requires conceptual and analytical clarity. In the literature there are several ways of thinking about accountability (see Fox 2014):

- Vertical/horizontal: Vertical accountability is the relationship between voters and elected representatives such as village health committees or patient committees. Horizontal accountability relationships are the mutual oversight of institutional checks and balances that include public administration and reporting systems, audit institutions, and the judicial system.

- 'Short' / 'long' route: A distinction is made between 'long route accountability', in which citizens influence policy makers that shape services, or a 'short route' whereby citizens directly influence services providers. Thus, citizens or users of services may influence (1) policy makers via votes, taxes, and parliament or (2) providers via client power, associations, and grievance committees.

- 'Supply'/'Demand': Society-led demand for 'good governance' is distinguished from government led 'supply-side' reforms.

Overall, while there are some consistent elements, there is no commonly accepted definition of social accountability in the literature. It varies in terms of the how the process is articulated, whether it occurs upstream or downstream in the policy process, what outcomes are envisioned, and so on. As a result of this "terminological looseness" (Holland et al. 2009), some have found it difficult to draw generalizable conclusions on the impact and effectiveness of social accountability interventions (Ringold et al. 2012). 


\section{SOCIAL ACCOUNTABILITY IN THE HEALTH SECTOR}

In recent years, social accountability has been seen as one of many ways to strengthen health systems, which are often one of the largest categories of public expenditure. Social accountability interventions are considered particularly useful in reducing the misuse of public resources (corruption), staff vacancies, poor infrastructure (George 2003), and ensuring that resources are used according to legal procedures, professional standards, and societal values (Brinkerhoff 2004). Health policy, therefore, increasingly focuses on social accountability as a means of improving quality of services and increasing the uptake of services, using such mechanisms as consumer charters, hospital boards, or village health committees (Brinkerhoff 2004; George 2007; Murthy and Klugman 2004). While some of these approaches may be new, direct community engagement has long been seen as part of good health service delivery.

Social accountability in health care is unique in that it happens within the context of health systems, which are a complex network of connected stakeholders with varying degrees of influence at different points in the service delivery process. These stakeholders may include health ministers, insurance agencies, public and private providers, legislatures, finance ministries, regulatory agencies, and health boards (Brinkerhoff 2004; Joshi 2013; Ringold et al. 2012). As a result, social accountability in the health sector can be seen as taking place at two levels (Brinkerhoff 2004; Joshi 2013):

- Systems level: Where policy decisions and institutional arrangements affect how human and financial resources are allocated and used.

- Service level: Where the interface between the infrastructure, client, and provider determines the quality of services provided to the client.

\section{TYPES OF SOCIAL ACCOUNTABILITY INTERVENTIONS}

Social accountability interventions take many forms. While they are conceptually linked by the set of assumptions discussed earlier, specific interventions differ significantly in form and scope, ranging from participatory mechanisms such as client charters and participatory budgeting to watchdog functions such as scorecards. Appendix 1 provides a detailed overview of the different approaches to promoting social accountability. These approaches are not mutually exclusive, and are often combined in a suite of complementary and interconnected activities. These approaches are summarized below:

- Participatory budgeting allows citizens direct participation in all phases of the budget cycle: formulation, decision making, and monitoring of budget execution. This is intended to increase citizens' voices in the budgeting process, increase transparency, and improve targeting of public spending. Goldfrank (2006) documents the use of participatory budgeting in Brazil, where it was first used to successfully improve transparency, increase direct citizen participation, and redistribute financial resources. In other countries such as Bolivia, Guatemala, Nicaragua, and Peru, however, participatory budgeting has had mixed effects due to a range of factors including whether there are municipal revenues to invest in public works or whether there is a tradition of participation by and cooperation within local civil society, to name a few.

- Public expenditure tracking (PET) involves civil society in monitoring budget execution by tracking flows of public resources for provision of public services and goods. PET is a 
good diagnostic tool to identify problems, such as leakages of funds or goods, or problems with service delivery, such as staff absenteeism. Sundet's (2008) review of PET's application to educational grants from central government to local schools in Uganda showed impressive results. In 1995, only 26 percent of the cash intended for primary schools made it to its destination whereas in 2002, after regular expenditure tracking, 80 percent of funds transferred to schools from the central government were received.

- Citizen report cards are participatory surveys that solicit user feedback on public service performance. Reports cards are useful for assessing service performance to improve quality, accessibility, and relevance of services, and reduce leakages and corruption. In Bangalore, Ravindra (2004) found that the use of citizen report cards to assess users' satisfaction with service performance increased public awareness of the quality of services and stimulated demand for better services.

- Social audits engage citizens, service users, or civil society organizations in collecting and publicly sharing information on available resources allocated for service delivery and public works.

- Community scorecards, a process of community-based monitoring, combine social audits and citizen report cards. Scorecards compile information on the demand side (user perspectives) and the supply side (service provider perspectives) of a particular service, and the data are then reviewed by all parties in an 'interface meeting' to allow for immediate feedback and action plan development. Dufils (2010) describes how a community scorecard, or "local governance barometer," in Madagascar was used to successfully identify blockages in program implementation and include all parties in designing a practical approach for addressing the blockages.

- Citizen charters articulate guidelines for the client and provider relationship, providing detail on what standards a client can expect and demand. Charters aim to raise awareness about service standards and client entitlements, and share the expectations and standards that providers agree to uphold.

- Health committees involve civil society and government working together in an institutionalized oversight body to improve health system effectiveness. Health committee structures aim to ensure community participation in decision-making. Loewenson et al. (2004) assessed the impact of Health Center Committees on service performance and found that clinics with health committees, on average, had more staff, higher budget allocations, greater drug availability, and better health statistics.

- Information sharing or campaigns are efforts usually led by civil society organizations to inform citizens and duty bearers about citizens' rights to services and quality performance standards. These campaigns are intended to increase awareness of services and benefits, service provider performance, and efforts to tackle corruption and fraud. Reinikka and Svensson (2011) describe how a newspaper campaign in Uganda targeting corruption in public education reduced misuse of public education funds and contributed to a positive effect on enrollment and student learning.

- Complaint mechanisms are formal channels to express dissatisfaction with a service and demand redress. Submitting complaints to a suggestion box or an ombudsman are examples of complaint mechanisms. Maru (2010) found, in many cases, social accountability interventions failed to have a positive impact because of a distinct lack of formal complaint mechanisms and redress. 
There has been a recent shift from focusing on specific social accountability interventions, such as report cards or social audits, to looking at the strategic steps required for a desired change. Several authors suggest that social accountability should be thought of as a change process with citizen engagement and action to elicit a state response instead (Fox 2014; Joshi 2013; Tembo 2013). In his review of social accountability interventions, Fox (2014) confirms that interventions which employed a strategic planning process had more positive outcomes than those that focused solely on tools. However, as the following discussion on theories of change illustrates, more effort is needed to articulate and document the implicit assumptions and steps that underpin this process.

\section{WHAT IS THE EVIDENCE ON EFFECTIVENESS AND IMPACT?}

While there are some encouraging examples in the literature about the value of social accountability interventions, overall the existing body of evidence about its effectiveness and impact is weak, incomparable, and inconclusive at best (Fox 2014; Holland et al. 2009; McGee and Gaventa 2011). Several reviews conclude that donors' expectations of accountability's impact are unreasonably high and not matched by the evidence (McGee and Gaventa 2011; Menocal and Sharma 2008; Molyneux et al. 2012; Ringold et al. 2012). This is widely attributed to methodological challenges in evaluating interventions rather than inherent failures in the approach of social accountability. Joshi (2013, p. 28) succinctly expresses these concerns:

Current social accountability practice has been racing abead of clear evidence of impact. The paucity of studies of impact (although increasing rapidly), the fragmentation of the data points, the lack of comparative evidence, the need for studies using mixed methods all have contributed to a situation where there is a strong normative belief in citizen-led accountability without a clear understanding of the conditions under which it can bave impact.

The lack of a rigorous body of evidence establishing a clear link between increased access and use of information, citizens' actions, and state responses can be attributed to a range of factors:

- When they are stated clearly, the focus tends to be on short- or medium term goals achievable in the project cycle, and not on tracking the longer term impact that may occur after the project has ended (Holland et al. 2009).

- A range of methods are used to study social accountability, including randomized control trials (RCTs), case studies, and participatory evaluations. The diversity of methodologies used in social accountability research makes it difficult to compare studies and draw general observations.

- Some methodologies may not be appropriate for assessing the impacts of social accountability interventions. Fox (2014) offers a critique of the evidence provided by RCTs, noting these studies intentionally unbundle complex and interrelated interventions to isolate effects.

- The studies tend to be descriptive with limited use of counterfactuals that can help demonstrate the relative effect of an intervention. Several efforts are now underway to address this gap (Ringold et al. 2012).

These challenges also affect the quality of evidence available on social accountability interventions to improve health and other services (Joshi 2012; Ringold et al. 2012). A few studies, like Bjorkman and Svenssen (2009), document clear outcomes: They conducted a RCT to test the effects of strengthening the relationship between health service providers and citizens to improve health care 
access and quality. This intervention compared community monitoring with report cards in 50 rural health facilities; after the first year, use of services, on average, was 16 percent higher in facilities where report cards were used. The bulk of evidence on social accountability in health is inconclusive, however (Brucker et al. 2011; Brinkerhoff 2004; Murthy and Klugman 2004; Ringold et al. 2012). Most studies document pilot projects and use research designs that are not able to attribute outcomes to specific interventions.

\section{WHAT ARE IMPORTANT ELEMENTS OF SOCIAL ACCOUNTABILITY INTERVENTIONS?}

Despite limited evidence on the impact of social accountability interventions, there is a growing consensus on the important elements of these activities. Based on the literature, five important conditions can be identified that are central to implementing effective social accountability efforts.

\section{A clearly articulated theory of change}

Joshi (2012) states that studies of social accountability are often clear on inputs and on the expected results, but their intermediate steps are vague at best. The standard formulation of how social accountability interventions affect change is:

- Greater information and transparency leads to greater awareness among citizens.

- Greater awareness leads to increased citizen engagement and empowerment leading citizens to take action.

- Action by citizens prompts decision-makers to react to increased scrutiny due to a sense of moral obligation or fear of reputational risk (Holland et al. 2009; McGee and Gaventa 2011).

Many implicit assumptions in this modeling require further interrogation. Do citizens have the capacity to effectively communicate demands to officials? Do service providers have the authority to make changes once a problem is identified? Do decision-makers have the resources to address citizen concerns?

Throughout the literature, there is a consensus about moving away from linear modeling toward a 'theory of change' when designing and measuring social accountability interventions (Holland et al. 2009; Joshi 2013; Ringold et al. 2012; Tembo 2013; Vogel 2012). Given that social accountability processes are unpredictable and highly politicized, the authors argue that the focus should be on the cascade of assumptions and outcomes in the design, implementation, and evaluation of a social accountability intervention. Joshi (2013, p. 9) notes:

A theory of change / causal chain approach allows one to understand implicit assumptions underlying particular activities, the conditions that are enabling and constraining as well as the extent to which interventions travel through the causal chain and reach immediate objectives even if the final outcomes are not those expected.

\section{Recognition that context matters}

The literature indicates that political, legal, and social contexts in which social accountability interventions occur are variable, stakeholders are not homogenous, and official decision-makers may 
not be the real brokers in everyday life. As Holland et al. (2009, p. 10) note, "in reality, of course, we must recognize that these 'ideal types' of governance relationships are heavily mediated and constrained by political economy factors, including the way that institutions function, and the power and interests of the stakeholders involved."

It is critical to understand how context influences outcomes and what factors enable or constrain change. Informal contextual factors such as the 'everyday politics' of communities, should be examined to identify how local level incentives and actions affect the outcomes of social accountability interventions (Tembo 2013). Formal contextual factors like the basic legal foundations (such as freedom of information acts, institutionalized citizen participation embedded in local government acts, institutionalized redress and grievance mechanisms) that protect and promote social accountability efforts should also be explored.

These contextual variables are further complicated in the health sector, as not all health delivery points are provided by governments or are in static settings. Private health care provision and mobile or peripheral service delivery mechanisms present challenges for social accountability interventions, as strategies for holding these providers accountable are less developed. Several methodologies have been identified for mapping relevant contextual factors as a first step in understanding this landscape, including outcome mapping, political economic analysis, and narratives of change (Joshi 2013; Tembo 2013).

\section{Awareness of values, power relationships}

An important assumption in the literature is that effective social accountability efforts first require changing individuals' attitudes and values, which then bring about changes in programs. To do this effectively, an essential element of social accountability programs is understanding the incentives and interests of different actors that drive change (Tembo 2013). These relationships may be unequal, but they are fluid, with opportunities for negotiation (George 2003).

The literature addressing health systems highlights specific asymmetries between providers, users, civil society groups, and oversight bodies with information, expertise, and access to services that make it difficult for citizens to assess providers' performances. The health system is characterized by formalized hierarchies and social norms-among service providers and between providers and clients - that affect behaviors, interests, and incentives. This may lead to a situation where citizens and clients are reluctant to challenge the authorities of providers (Murphy and Klugman 2004).

\section{Linkages to redress and remedy mechanisms}

The literature also indicates the importance of linking social accountability activities with official accountability mechanisms such as formal incentives and sanctions systems. Maru (2010) found, in many cases where social accountability failed to have a positive impact, there was a distinct lack of formal redress (also see Ringold et al. 2012). Similarly, Fox (2014) points out that few accountability initiatives are coordinated with relevant official accountability mechanisms and governance reforms (investigative bodies, information access reforms, ombudsmen, legal cases, anti-corruption agencies, elections, and media). Yet, throughout the literature there is more focus on information (transparency) and empowerment (voice) components of accountability over actions and sanctions to ensure state responsiveness.

Brinkerhoff (2004) identifies a range of routes for enforcing accountability through regulatory frameworks (e.g. licensing and accreditating service providers), health care financing and payment schemes, quality assurance policies, market competition, and public exposure or negative publicity. In 
addition to these enforcement mechanisms, there needs to be sufficient implementation capacity, often an implicit assumption.

Effective sanctions are not exclusively the result of litigation but can include the use of formal channels to express dissatisfaction with a service and demand redress. These channels can include options offered through government agencies such as hotlines or complaint offices, and independent redress mechanisms outside formal government bureaucracy such as tribunals, ombudsmen, and the judicial system (Ringold et al. 2012). Brinkerhoff (2004) also notes that enforcement is an essential element of incentivizing behavior, as "sanctions without enforcement significantly diminish accountability. Lack of enforcement and/or selective enforcement undermines citizens' confidence that government agencies are accountable and responsive, and contribute to the creation of a culture of impunity that can lead public officials to engage in corrupt practices" (373).

In the health sector, health policies create entitlements with a chain of responsibility for ensuring fulfillment. The legal system is the most commonly used system to address grievances (Ringold et al. 2012). Although legal redress can be costly, time-consuming, and inaccessible to many, it is one critical tool for bringing justice and reparation to individuals and communities.

\section{Presence of core enabling factors}

Finally, the literature highlights the importance of enabling and disabling factors that underpin the effectiveness of social accountability interventions. Appendix 2 outlines the range of key enabling factors identified in the literature. The following four most frequently identified are:

- Citizens have access to relevant information: Citizens know their entitlements, have the ability to access information about specific commitments and services as well as information about the relevant decision making processes. This can be generally thought of as transparency.

- Citizens have the capacity to use information: Once citizens have accessed the pertinent information they have the capacity to use information to support their demands.

- The State has the capacity to respond to citizens' requests: Once citizens' demands are made, duty bearers have the interest and capacity (staff, resources, and remittance) to respond to citizens' requests.

- Incentives and sanctions are in place to compel decision-makers to respond: This refers to the formal and institutionalized incentives and sanctions that compel duty bearers to act upon requests from citizens. 


\section{Social Accountability in the FP/RH Sector}

There is growing interest and momentum around accountability initiatives in the FP/RH sector. In many cases, these activities are broader than social accountability (which tends to focus on the community or service delivery level), focusing instead on tracking the fulfillment of global and national policy and financial commitments. A number of innovative programs are also applying the principles of social accountability to the challenge of delivering rights-based, voluntary, high-quality FP/RH services. This section reviews these programs' experiences, drawing on current understanding of social accountability programs discussed earlier.

\section{WHAT IS ‘SOCIAL ACCOUNTABILITY’ IN THE FP/RH SECTOR?}

The term accountability is in vogue in the FP/RH field, and builds on a history of attention to community and civil society involvement that has spanned several decades. The promotion of community participation in public health efforts to achieve improvements in health and well-being dates to the 1978 Declaration of Alma-Ata, an outcome of the International Conference on Primary Health Care. Community-based FP programming emerged as part of this trend (Askew and Khan 1990; Population Council 2004). Nearly two decades later, the International Conference on Population and Development (ICPD) contended that states should work with communities and their civil society representatives in enacting policy and designing and implementing programs to meet local needs, including RH needs (UNFPA 1994). Shortly thereafter, Catino (1999, p. 27) argued, "an informed and responsible public that demands quality sexual and reproductive health care, and holds governments and facilities accountable for providing it, is crucial for the effective reform of existing services."

More recent initiatives to improve aid effectiveness and promote country ownership are continuing to cast a light on the role of civil society in public health, including FP/RH (Dennis 2009; USAID et al. 2013). Communities are now expected to engage in program planning, design, and implementation, both to ensure that local health needs are met and that governments perform as desired - creating a feedback loop whereby programs for which communities advocate are implemented and evaluated (USAID et al. 2013). The traditions of tracking funding allocations and monitoring service delivery systems and their quality of care provide important precedents for social accountability efforts.

Drawing on this tradition, currently a wide range of accountability initiatives are taking place at the global, national, and health systems levels. Many of these FP/RH initiatives are listed in Table 2 and fall into three broad categories: (1) those that track donor and government financial commitments, which includes tracking budget line item allocations; (2) those that track specific elements of program implementation at the national level, such as commodity security or key coverage or impact indicators; and (3) those that track service delivery outcomes within a particular health system. Drawing on the definition of social accountability presented earlier, this review considers the third category — tracking service delivery outcomes—as constituting social accountability initiatives within the FP/RH field. 
Table 2: A Typology of the Architecture of FP/RH Accountability Initiatives

\begin{tabular}{|c|c|c|}
\hline $\begin{array}{l}\text { Categories of } \\
\text { FP/RH } \\
\text { Accountability } \\
\text { Activities }\end{array}$ & Organization & Illustrative Initiatives \\
\hline \multirow{9}{*}{$\begin{array}{l}\text { Tracking donor and } \\
\text { government financial } \\
\text { commitments }\end{array}$} & FP2020 & $\begin{array}{ll}\text { - } & \text { Performance Monitoring and Accountability } \\
\text { Working Group }\end{array}$ \\
\hline & $\begin{array}{l}\text { The Netherlands Inter- } \\
\text { Disciplinary } \\
\text { Demographic Institute }\end{array}$ & - $\quad$ Resource Flows for Family Planning \\
\hline & $\begin{array}{l}\text { World Health } \\
\text { Organization }\end{array}$ & $\begin{array}{l}\text { - National Health Accounts and System of } \\
\text { Health Accounts }\end{array}$ \\
\hline & $\begin{array}{l}\text { Population Action } \\
\text { International }\end{array}$ & - $\quad$ Budget Tracking Advocacy \\
\hline & DSW & - $\quad$ Euroleverage Project \\
\hline & $\begin{array}{l}\text { IPPF/ Western } \\
\text { Hemisphere Region }\end{array}$ & - Budget tracking in Mexico, Peru, and Bolivia \\
\hline & Health Policy Project & - $\quad$ Budget analysis in India and Nigeria \\
\hline & $\begin{array}{l}\text { The Kaiser Family } \\
\text { Foundation }\end{array}$ & - Donor budget tracking \\
\hline & $\begin{array}{l}\text { Reproductive Health } \\
\text { Supplies Coalition }\end{array}$ & $\begin{array}{l}\text { - Advocacy and Accountability Working } \\
\text { Group }\end{array}$ \\
\hline \multirow{5}{*}{$\begin{array}{l}\text { Tracking national-level } \\
\text { program } \\
\text { implementation }\end{array}$} & The Gates Institute & $\begin{array}{ll}\cdot & \text { PMA2020 } \\
\text { - } & \text { Advance Family Planning (AFP) } \\
\end{array}$ \\
\hline & John Snow Inc. & - The Deliver Project \\
\hline & Futures Institute & - $\quad$ Track20 Initiative \\
\hline & $\begin{array}{l}\text { Partnership for Maternal, } \\
\text { Newborn and Child } \\
\text { Health }\end{array}$ & - Countdown to 2015 \\
\hline & IPPF & $\begin{array}{l}\text { - Commodity Security in Uganda, Ghana, and } \\
\text { Bangladesh }\end{array}$ \\
\hline \multirow{6}{*}{$\begin{array}{l}\text { Tracking service } \\
\text { delivery provision and } \\
\text { outcomes }\end{array}$} & Pathfinder International & $\begin{array}{l}\text { - Community Scorecard and Report Card in } \\
\text { Tanzania }\end{array}$ \\
\hline & CARE & - $\quad$ Community Scorecard in Malawi \\
\hline & IPPF & $\begin{array}{l}\text { - } \text { Social Audits in Dominican Republic and } \\
\text { Panama } \\
\text { - Social Audits in Nepal } \\
\text { - Sexual Rights Health Providers Self- } \\
\text { - Assessment } \\
\text { - } \quad \text { Beneficiary Feedback work } \\
\end{array}$ \\
\hline & White Ribbon Alliance & - "Social Watch" in various countries \\
\hline & JHPIEGO & $\begin{array}{l}\text { - Commodities Scorecard/Client Charters in } \\
\text { Kenya }\end{array}$ \\
\hline & FOWEDE & - Community Scorecard in Uganda \\
\hline
\end{tabular}

While this review focuses specifically on the category of social accountability activities that relate to tracking service delivery outcomes, it is useful to reflect on the links among the three categories of accountability activities. In their discussion of the different aims of accountability efforts in the FP/RH field, Freedman and Schaaf (2013) note that many global initiatives make the basic assumption that increased visibility will create necessary pressure on national decision-makers that lead them to enact desired policy, budgetary, or programmatic changes, yet they identify a large gap between global dialogue and action and its application at the local level. They argue that all global 
level activity has not yet translated into global improvements in local services, which remain limited, discriminatory, of insufficient quality, often with high rates of provider absenteeism, and commodity leakages in too many countries. As a result, social accountability efforts are also urgently needed to strengthen services at the local level.

\section{Types of social accountability initiatives in FP/RH}

This paper's literature searches found limited literature on specific social accountability activities in the FP/RH field. Sixteen articles were identified that addressed FP/RH-specific accountability activities, several of which involved multi-country initiatives. They represented geographically diverse populations, with experiences from Latin America, South Asia, and Africa. All studies included FP as a health service component that the interventions sought to improve, although many programs were framed as broader RH or maternal health activities. The bulk of these experiences were found in the grey literature and consisted primarily of project reports or other deliverables. These intervention studies are summarized in Appendix 3.

As noted in Section 2, nine types of accountability initiatives can be identified in the general literature on social accountability: participatory budgeting, public expenditure tracking, citizen report cards, social audits, community scorecards, citizen charters, health committees, information sharing or campaigns, and complaint mechanisms. The most common types of initiatives in the literature reviewed on $\mathrm{FP} / \mathrm{RH}$ are:

- Public expenditure tracking (IPPF 2012; Malajovich et al. 2012)

- Citizen report cards (Pathfinder International 2013; Goicolea et al. 2008)

- Social Audits: (Subha et al. 2012; HPI-Task Order 1. 2010)

- Community score cards (CARE 2011; CARE 2012)

- Health committees (Corrêa et al. 2005; Parkes 2001; Shiffman 2012)

- Information sharing or campaigns (Brucker et al. 2011; Papp et al. 2012)

This range of approaches used in FP/RH social accountability initiatives may suggest these few are most suited to the FP/RH sector's unique needs, where quality of care is closely related to rights and choice. It may also suggest, given the recent emergence of social accountability initiatives for $\mathrm{FP} / \mathrm{RH}$, that these models are the first of many to be tested. Additional research is required to determine which types of accountability initiatives are most relevant to $\mathrm{FP} / \mathrm{RH}$ programs, and when and how they are best implemented.

\section{WHAT IS THE EVIDENCE ON EFFECTIVENESS AND IMPACT?}

As with the general literature on social accountability, the body of evidence documenting the impact of these initiatives is underdeveloped and suffers from the same type of methodological challenges identified earlier, in which anticipated outcomes are not fully specified, counterfactuals are absent, and studies are not readily comparable. In many cases the content of social accountability interventions are not documented fully, especially in peer-reviewed publications, limiting the ability to draw lessons from different intervention types. Because much of the knowledge base is from the grey literature, often from program documentation and final reports, the quality and rigor of the data 
reported are variable. As a result, the impact and effectiveness of social accountability interventions for $\mathrm{FP} / \mathrm{RH}$ has yet to be adequately demonstrated.

Nonetheless, some notable findings emerge from individual studies. Half of the case study papers reviewed report some demonstrable outcomes from their social accountability initiatives. For example:

- In Mexico, IPPF (2012) reported that budget analysis and advocacy activities by a consortium of national civil society partners increased funds for state implementation of adolescent sexual and reproductive health and rights policy. In 2011, an additional USD \$7.8 million was allocated, with another USD \$15.6 million allocated in 2013.

- In Peru, CARE (2012) documented increased rates and timeliness of health seeking behaviors and decreased maternal deaths after four years of client charters for maternal rights.

- In Nepal, Gryboski et al. (2006) saw an increase in women seeking antenatal care for first pregnancy in study settings with community scorecard activities, although contraceptive use did not notably improve.

- Within five months of implementing the White Ribbon Alliance's social accountability program in Tanzania, HPITask Order 1 (2010) documented a 33 percent increase in staffing patterns at 24 intervention facilities.

\section{DO FP/RH INTERVENTIONS INCLUDE THE IMPORTANT ELEMENTS OF SOCIAL ACCOUNTABILITY?}

The literature on social accountability reviewed in Section 2 found, while evidence on overall effectiveness is limited, there is emerging consensus on the core elements of successful accountability interventions. A discussion of the relevance of these elements applied to FP/RH social accountability interventions aids better understanding of the strengths and gaps in the literature.

\section{Clearly articulated theory of change}

The literature presented in Section 2 argues for the importance of clearly articulating a theory of change underpinning basic assumptions. This element, however, is consistently missing in the $\mathrm{FP} / \mathrm{RH}$ literature included in this review. None of the 16 papers provide precise details on their activities, the process through which reported changes occurred, or what factors influenced their conclusions. One clear recommendation for future programming and documentation efforts in the $\mathrm{FP} / \mathrm{RH}$ sector is that all assumptions informing social accountability interventions should be explicitly articulated and evaluated.

\section{Recognition that context matters}

Most of the 16 case studies stress the importance of context in shaping social accountability outcomes, particularly the institutional context of the health system. The majority of studies emphasize the importance of decentralization, an increasingly prominent governance approach in low and middle income countries (Brucker et al. 2011; Corrêa et al. 2005; Parkes 2001). Ideally, decentralization should shift priority-setting closer to communities, yet many of these studies report how local governments lack the skills, authority, and resources to address identified service delivery 
constraints. This is an important constraint for FP/RH services, which require both technical knowledge and an understanding of rights-based approaches.

Another contextual issue identified in the literature is the variety of service delivery points through which FP/RH services are provided. Many interventions reviewed focus on improving public, facility-based service delivery. Freedman and Schaaf (2013), however, note that the state is not the only FP/RH service provider and that social accountability frameworks need to explicitly include provisions for influencing non-state actors. This concern is especially relevant as the FP sector moves toward a "total market approach" that recognizes the roles of public, non-profit, and commercial service providers in expanding access to FP services. New research (and potentially new models) is needed to demonstrate the applicability of social accountability approaches across the market.

\section{Awareness of values, power relationships}

Power dynamics were frequently addressed in the literature on social accountability for FP/RH, with authors noting that significant power differentials exist between providers, decision-makers, and clients and that these dynamics may prevent clients from voicing their needs, priorities, and issues, undermining social accountability efforts (Care 2012; HPI-Task Order 1 2010; Gryboski et al. 2006; Goicolea et al. 2008; Subha et al. 2012). Health workers and officials may be reluctant to admit weaknesses, and may become defensive and even enact reprisals (Papp et al. 2012).

Other papers also note the need to protect marginalized clients' rights in social accountability initiatives (Subha et al. 2012). FP/RH clients can be marginalized or excluded due to ethnicity, age, marital status, or location, and may be unable to represent their specific needs. Some papers recommended actions to counteract marginalization including disaggregating data so different groups' needs are represented as well as ensuring that their problems are focused on and validated (Goicolea et al. 2008; CARE 2011).

\section{Links to redress and remedy mechanisms}

No paper addresses the issue of redress or remedy as part of FP/RH social accountability. There was little focus on incentives and sanctions to ensure responses from duty bearers. Instead, papers emphasize the need to collaborate and support service providers and local officials in place of a more adversarial approach that threatens sanctions and reputational risk (Brucker et al. 2011; Corrêa et al. 2005; HPI-Task Order 1 2010; Parkes 2001).

\section{Presence of core enabling factors}

As with social accountability more broadly, an important factor identified in the papers on FP/RH is citizens' levels of awareness about their entitlements and of their capacity to use information. A common issue identified is the lack and quality of information (Brucker et al. 2011; Correa et al. 2005; HPITask Order 1 2010; Malajovich et al. 2012; Subha et al. 2012). Much of the accountability information was fragmented, inaccessible, or simply does not exist. This is a perennial concern in the health sector, and one that social accountability initiatives will have to effectively grapple with to succeed.

Empowering and engaging clients are complemented by a focus on collaborating and supporting service providers and officials. Both parties are essential to the 'call and response' of social accountability. Several authors refer to the need to work closely with service providers and officials, by providing training, proposing realistic solutions, using anonymized data and coordinating with 
local planning processes (Care 2011; Corrêa et al. 2005; Futures Group 2010; Papp et al. 2012; Parkes 2001). Better understanding of how to support service providers and officials in FP/RH programming may be an area for further development. 


\section{Conclusions}

This paper aims to consolidate and analyze the current literature on social accountability in different sectors to identify lessons that can be applied to the FP/RH sector. Overall, it finds the field of social accountability is a dynamic one, with a variety of initiatives and interventions at different levels and contexts, including the FP/RH field. Despite important gaps, the literature does convey the importance of the role social accountability interventions can likely play in improving service delivery, including $\mathrm{FP} / \mathrm{RH}$ programming.

Looking specifically at the FP/RH literature, the picture of social accountability initiatives that emerges is incomplete, not capturing the range of activities currently underway in the field. The limited literature reviewed for this paper also does not provide clear evidence on the effectiveness of the different approaches documented, which is critical for advancing the field.

Drawing on the existing evidence base, overarching issues and observations relevant to the FP/RH sector emerge, as follows:

\section{FP/RH SOCIAL ACCOUNTABILITY PROGRAMMING}

- More thinking is needed about whether social accountability for FP/RH differs from initiatives for broader health systems issues, and if so, how. It is critical to establish whether the field of FP/RH is so unique that it requires unique social accountability approaches. One answer may involve the cornerstones of quality FP/RH service provision-choice and voluntarism — and determining how they interact with the principles of transparency and state responsibility inherent in the social accountability paradigm.

- More clarity is needed on how social accountability and rights-based work can complement one another, as the two are not interchangeable. The two approaches are not mutually exclusive, and can be complementary, yet it is critical not to assume that social accountability will necessarily be based on a rights-based approach.

- There is a need to focus on bolstering state capacity to respond to service delivery shortcomings, either through incentives, sanctions, or links with official redress mechanisms. Social accountability requires enforcement 'teeth' to respond to questions about obligations as well as sanctions for failures and transgressions. Incentives and sanctions for providers and government officials in FP programs have a questionable past, however, sometimes associated with coercion and rights violations. The FP/RH field has to think very carefully about how they are applied and operationalized.

- There is also a need to think more broadly about how the principles of social accountability can be applied outside the traditional health sector. FP/RH services are becoming more widely accessible in alterative service delivery channels such as drug shops, pharmacies, social franchises, and mobile service outlets. Ensuring quality of care with the new realities in $\mathrm{FP} / \mathrm{RH}$ service delivery may require adaptations to existing approaches and tools of social accountability. 


\section{BUILDING THE EVIDENCE BASE}

- The evidence base on the effectiveness of social accountability initiatives in general, and those specifically focused on FP/RH, remains limited. Much of this is due to methodological limitations that compromise generalizable conclusions from the literature, and to address this more and better documentation, monitoring, and evaluation strategies are required. This does not necessarily imply the need for a standard methodological approach, such as RCTs, but does suggest the need for more rigor in articulating and evaluating such interventions.

- In building the evidence base for what works in the FP/RH field, it would be expedient to focus on social accountability interventions with some track record in achieving positive outcomes, such as social audits, community monitoring, and health committees. Such interventions could benefit from an implementation science approach examining not only outcomes but their actual implementation strengths and shortcomings.

- An important element in ensuring better evaluation of social accountability initiatives is clearly articulating the assumptions of each intervention's theory of change. This is a challenge throughout the literature, and is especially pronounced in the documentation of $\mathrm{FP} / \mathrm{RH}$ social accountability activities.

- The literature is silent on questions of sustainably and the scalability of social accountability activities. It is clear that 'context matters', as well as interpersonal relationships and community power dynamics. Given this, what does the concept of 'scaling up', which implies replication and expansion of an intervention, mean for social accountability interventions? 


\section{References}

Agarwal, Sanjay, Rasmus Heltberg, and Myrtle Diachock. 2009. "Scaling Up Social Accountability in World Bank Operations,” Washington DC: World Bank.

Askrew, Ian and AR Khan. 1990. "Community participation in national family planning programs: some organizational issues," Studies in Family Planning 21(3):127-42.

Arroyo, Dennis, and Karen Sirker. 2005. "Stocktaking of Social Accountability Initiatives in the Asia and Pacific Region," The World Bank Institute Community Empowerment and Social Inclusion Learning Program.

Banerjee, Abhijit, Esther Duflo, Rachel Glennerster, Rukmini Banerji , and Stuti Khemani. 2010. "Pitfalls of Participatory Programs: Evidence from a Randomized Evaluation of Education in India," American Economic Journal: Economic Policy 2(1): 1-30.

Bjorkman, Martina, and Jakob Svenssen. 2009. "Power to the People: Evidence from a Randomized Field Experiment on Community-Based Monitoring in Uganda," The Quarterly Journal of Economics 124(2): 735-769. Accessed on June 302014 from: http://qje.oxfordjournals.org/content/124/2/735.short

Brinkerhoff, Derick W. 2004. "Accountability and health systems: toward conceptual clarity and policy relevance," Health Policy and Planning 19(6): 371-379.

Brucker, Matthias, Katrin Kubica, Manka Kway, Anne A. Sizomu, and Caroline Teti. 2011. "Decentralisation, social accountability and family planning services: The cases of Uganda, Kenya and Tanzania," 2nd International Conference on Family Planning: Research and Best Practices. November 29 - December 2, 2011.

CARE. 2012. “Women’s Lives, Women's Voices: Empowering women to ensure family planning coverage, quality and equity," CARE International. Accessed on June 302014 from: http://www.care.org/sites/default/files/documents/FP-Summit-Report-2012L.pdf

CARE. 2011. "The Community Scorecard in Tanzania," CARE Tanzania. Accessed on June 302014 from: governance.care2share.wikispaces.net/file/view/CARE_Tanzania_CommunityScoreCard.pd f/433865266/CARE_Tanzania_CommunityScoreCard.pdf

Caseley, Jonathan. 2003. "Blocked Drains and Open Minds: Multiple Accountability Relationships and Improved Service Delivery Performance in an Indian City," IDS Working Paper 211, Brighton: Institute of Development Studies.

Catino J. 1999. "Meeting the Cairo challenge: progress in sexual and reproductive health. Implementing the ICPD Programme of Action,” New York: Family Care International.

Chowdhury, Sadia, Petra Vergeer, Harald Schmidt, Helene Barroy, David Bishai, and Scott Halpern. 2013. Economics and Ethics of Results-Based Financing for Family Planning: Evidence and Policy Implications. HNP Discussion paper. Washington DC: The World Bank. Accessed on June 302014 from: http://documents.worldbank.org/curated/en/2013/12/18933867/economics-ethics-resultsbased-financing-family-planning-evidence-policy-implications 
COPASAH. 2014. Website: Community of Practitioners on Accountability and Social Action in Health. Accessed on June 302014 from: http:/ /www.copasah.net/

Corrêa, Sonia, Peter McIntyre, Carla Rodrigues, Anabela Paiva, and Cecilia Marks. 2005. "The Population and Reproductive Health Programme in Brazil 1990-2002: Lessons Learned: A Report to the John D and Catherine T MacArthur Foundation," Reproductive Health Matters 13(25):72-80.

Cronin, Donal, and John O’Regan. 2002. “Accountability in Development Aid: Meeting Responsibilities, measuring Performance,” Research Report for Cómhlamh Aid Issues Group. Accessed on June 302014 from: http://www.dochas.ie/Shared/Files/4/Comhlamh_Research.pdf

Dennis, Suzanna. 2009. "Making Aid Effectiveness Work for Family Planning and Reproductive Health.” PAI Working Paper WP 09-03. Washington, DC: Population Action International.

Department for International Development. 2011. "Empowering Poor People and Strengthening Accountability," Summary Note from DFID. Accessed on June 302014 from: https://www.gov.uk/government/uploads/system/uploads/attachment_data/file/67465/e mpower-account-summary-note.pdf

Diaz, Margarita, Ruth Simmons, Juan Diaz, Carlos Gonzalez, Maria Y. Makuch and Debora Bossemeyer. 1999. "Expanding contraceptive choice: findings from Brazil," Studies in Family Planning 30(1): 1-16.

Dufils, J. 2010. “Local Governance Barometer: Measuring Governance in Madagascar,” In: Claasen, M. and Alpin-Lardiés, C. (eds), Social Accountability in Africa: Practitioners Experiences and Lessons, Pretoria: Idasa and Affiliated Network for Social Accountability.

Duggal, Ravi. 2005. "Public hearings and litigations: the new medicine for policy reform," Express Healthcare Management January 2005: 1-15.

Fox, Jonathon. 2014. "Social accountability: What does the evidence really say?” GPSA Working Paper 1. Global Partnership for Social Accountability. Accessed on October 62014 from: http://gpsaknowledge.org/knowledge-repository/social-accountability-what-does-theevidence-really-say-2/\#.VDKlfRZsQ8t

FP2020. 2012. "London Summit on Family Planning - July 11, 2012," Summit Overview. Accessed on June 302014 from: http://www.familyplanning2020.org/images/content/old_site_files/London-SummitFamily-PlanningOverview_V1-14June.pdf

Freedman, Lynn P., and Marta Schaaf. 2013. "Act global, but think local: accountability at the frontlines,” Reproductive Health Matters 21(42):103-112.

Gauthier, Bernard. 2006. "PETS -QSDS in Sub-Saharan Africa: A Stocktaking Study," Washington DC: World Bank.

George, Asha. 2003. "Using accountability to improve reproductive health care," Reproductive Health Matters 11(21):161-170.

Goetz, Anne Marie, and Rob Jenkins. 2002. "Voice, Accountability and Human Development: The Emergence of a New Agenda," Background Paper for UNDP, Human Development Report 2002: Deepening Democracy, New York: UNDP. 
Goicolea, Isabel, Miguel San Sebastian, and Marianne Wulff. 2008. "Women's reproductive rights in the Amazon basin of Ecuador: challenges for transforming policy into practice," Health Hum Rights 10(2): 91-103.

Goldfrank, Benjamin. 2006. "Lessons from Latin American Experience in Participatory Budgeting," Paper Presented at the Latin American Studies Association Meeting, San Juan, Puerto Rico. Accessed on June 302014 from: http://www.internationalbudget.org/themes/PB/LatinAmerica.pdf

Gryboski, Kristina, Nancy Yinger, Ricardo Dios, Heidi Worley, and Fariyal Fikree. 2006. "Working with the community for improved health," Health Bulletin No. 3. Washington DC: Population Reference Bureau.

Hardee, Karen, Jan Kumar, Karen Newman, Lynn Bakamjian, Shannon Harris, Mariela Rodriguez, and Win Brown. 2014. "Voluntary, human rights-based family planning: A conceptual framework," Studies in Family Planning 45(1): 1-18.

Health Policy Initiative-Task Order I (HPI). 2010. "Promoting Accountability for Safe Motherhood: The White Ribbon Alliance's Social Watch Approach,” Health Policy Initiative Task Order 1. Accessed on June 302014 from: www.healthpolicyinitiative.com/Publications/Documents/1282_1_Social_Watch_WRA_HP I_FINAL_acc.Pdf

Hoffmann, K.D. 2014 “The Role of Social Accountability in Improving Health Outcomes: Overview and Analysis of Selected International NGO Experiences to Advance the Field." Washington, DC: CORE Group.

Holland, Jeremy, Allyson Thirkell, Emmanuel Trepanier, and Lucy Earle. 2009. "Measuring Change and Results in Voice and Accountability Work," Working Paper 34. London: Department for International Development.

Ogden, J., K. Morrison, and K. Hardee. 2012. "Social Capital to Strengthen Health Policy and Health Systems.” Working Paper \#6. Washington, DC: Futures Group, Health Policy Project.

Overy, Neil. 2010. "Impact Case Study of Civil Society Interventions Around the Child Support Grant in South Africa," From Analysis to Impact Case Study Series. South Africa, International Budget Partnership. Accessed on July 12014 from: http://internationalbudget.org/publications/south-africa-civil-society-uses-budget-analysisand-advocacy-to-improve-the-lives-of-poor-children/

IPPF. 2012. "Holding Governments Accountable: Experiences from Five Latin American Countries," International Planned Parenthood Western Hemisphere region. Accessed on June 302014 from: https://www.ippfwhr.org/en/publications/holding-governmentsaccountable-experiences-from-five-latin-american-countries

Iwami, Michiyo, and Roland Petchey. 2002. "A CLAS act? Community-based organizations, health service decentralization and primary care development in Peru," Journal of Public Health Med. 24(4):246-51.

Jacobs, Bart, Neil Price, and Sam Oeun Sam. 2007. "A sustainability assessment of a health equity fund initiative in Cambodia," The International Journal of Health Planning and Management 22(3):183-203. 
Jenkins, Rob. 2007. “India's Unlikely Democracy: Civil Society versus Corruption,” Journal of Democracy 18(2):55-69.

Joshi, Anuradha. 2010. "Review of Impact and Effectiveness of Transparency and Accountability Initiatives: Service Delivery," Paper prepared for the Transparency and Accountability Initiative Workshop October 14 - 15, 2010. London: Institute of Development Studies. Accessed on June 302014 from: https://www.ids.ac.uk/files/dmfile/IETAAnnex1ServicedeliveryJoshiFinal28Oct2010.pdf

Joshi, Anuradha. 2013. "Context Matters: a Causal Chain Approach to Unpacking Social Accountability Interventions," Paper prepared for Face-to-Face Meeting. Egypt: IDSDLGN. Accessed on June 302014 from: https://www.ids.ac.uk/files/dmfile/ContextMattersaCasualChainApproachtoUnpackingSAi nterventionsAJoshiJune2013.pdf

Khemani, Stuti. 2008. "Does Community Monitoring Improve Public Services? Diverging Evidence from Uganda and India," Research Brief, Human Development and Public Services Research, Washington DC: World Bank.

Loewenson, Rene, Itai Rusike, and Memory Zulu. 2004. "Assessing the impact of Health Centre Committees on health system performance and health," Final report, EQUINET Discussion Paper 18. Training and Research Support Centre Zimbabwe Community Working Group on Health.

Malajovich, Laura, Maria Antonieta Alcalde, Kelly Castagnaro, and Carmen Barroso. 2012. "Budget transparency on maternal health spending: a case study in five Latin American countries," Reproductive Health Matters 20(39):185-195.

Malena, Carmen, Reiner Forster, and Janmejay Singh. 2004. "Social Accountability: An Introduction to the Concept and Emerging Practice," Social Development Paper No. 76. Washington, DC: World Bank.

Maru, Vivek. 2010. “Allies Unknown: Social Accountability and Legal Empowerment,” Health and Human Rights in Practice 12(1)83-93.

McGee, Rosemary, and John Gaventa. 2011. "Synthesis report: Review of Impact and Effectiveness of Transparency and Accountability Initiatives," Prepared for the Transparency and Accountability Initiative Workshop, October 14 - 15, 2010. London: Open Society Foundation Transparency and Accountability Initiative. Accessed on June 302014 from: https://www.ids.ac.uk/files/dmfile/IETASynthesisReportMcGeeGaventaFinal28Oct2010.p df

Menocal, Alina Rocha, and Bhavna Sharma. 2008. "Joint Evaluation of Citizens' Voice and Accountability: Synthesis Report,” London: DFID.

Misra, Vivek, P. Ramasankar, J.V.R. Murty, Sanjay Agarwal, and Parmesh Shah. 2007. "Pilot Study 1, Andhra Pradesh, India: Improving Health Services through Community Scorecards," Learning Notes, Social Accountability Series. Washington, DC: World Bank.

Molyneux, Sassy, Martin Atela, Vibian Angwenyi, and Catherine Goodman. 2012. "Community accountability at peripheral health facilities: a review of the empirical literature and development of a conceptual framework," Health Policy and Planning 27(7):541-54. 
Murthy, Ranjani K., and Barbara Klugman. 2004. "Service accountability and community participation in the context of health sector reforms in Asia: implications for sexual and reproductive health services," Health Policy and Planning 19(S1):i78-i86.

O’Meally, Simon C. 2013. "Mapping Context for Social Accountability: A Resource Paper," Social Development Department, World Bank, Washington, DC.

O’Neill, Tammie, Marta Foresti, and Alan Hudson. 2007. "Evaluation of Citizens' Voice and Accountability: Review of the Literature and Donor Approaches," London: DFID.

Ouagadougou Partnership. 2012. Family Planning: Francophone West Africa on the Move, a Call to Action," The Ouagadougou Partnership. Accessed on June 302014 from: http://advancefamilyplanning.org/sites/default/ files/resources/ouagadougoupartnership_en.pdf

Pandey, Priyanaka, Sangeeta Goyal, and Venkatesh Sundararaman. 2008. "Community Participation in Public Schools: The Impact of Information Campaigns in Three Indian States," Policy Research Working Paper 4776. World Bank, Washington, DC. Accessed on June 302014 from: http:/ / econ.worldbank.org/external/default/main?pagePK=64165259\&piPK=64165421\&t heSitePK=469382\&menuPK=64216926\&entityID=000158349_20081111142153

Papp, Susan A., Aparajita Gogoi, and Catherine Campbell. 2012. "Improving Maternal health through social accountability: A case study from Orissa, India," Global Public Health 8(4):449-464.

Parkes, Kate. 2001. “Ghana's Participation Programme, 1996-2000: Reproductive Health Advocacy at District, Subdistrict, and Community Levels in the Eastern Region," Washington DC: POLICY Project.

Pathfinder International. 2013. "Us of the Citizen Report Card to Assess Local Family Planning Need in Tanzania," Watertown, MA, Pathfinder International. Accessed on June 302014 from: http://www.pathfinder.org/publications-tools/pdfs/Use-of-the-Citizen-Report-Cardto-Assess-Local-Family-Planning-Need-in-Tanzania_Sept-2013_FINAL.pdf

Pawson, Ray, Tisha Greenhalgh, Gill Harvey, and Kieran Walshe. 2005. "Realist review-a new method of systematic review designed for complex policy interventions," Journal of Health Services Research and policy 10(1):21-34.

Population Council. 2004. "Linking Reproductive Health to Social Power: Community Health Workers in Belize and Pakistan.” Quality/Calidad/Qualite. New York: Population Council.

Results for Development. 2014 Accelerating Progress in Family Planning: Options for Strengthening CSO-led Monitoring and Accountability (forthcoming)

Ravindra, Adikeshavalu. 2004. "An Assessment of the Impact of Bangalore Citizen Report Cards on the Performance of Public Agencies," Evaluation Capacity Development Working Paper 12, Operations Evaluation Department, Washington DC: World Bank.

Reinikka, Ritva, and Jakon Svensson. 2011. "The Power of Information in Public Services: Evidence from Education in Uganda.” Journal of Public Economics 95(7-8):956-966. 
Ringold, Dena, Alaka Holla, Margaret Koziol, and Santhosh Srinivasan. 2012. "Citizens and Service Delivery: Assessing the Use of Social Accountability Approaches in Human Development," Direction in Development: human Development. Washington DC: The World Bank.

Saha, Somen, Peter Leslie Annear, and Swati Pathak. 2013. "The effect of Self-Help Groups on access to maternal health services: evidence from rural India," International Journal for Equity in Health 12:36.

Shiffman, Jeremy. 2012. "The construction of community participation: village family planning groups and the Indonesian state," Sci Med. 54(8):1199-214.

Singh, Ritesh, and Vinay Vutukuru. 2010. "Enhancing Accountability in Public Service Delivery through Social Audits: A Case Study of Andhra Pradesh," Accountability Initiative, New Delhi: Centre for Policy Research. Accessed on July 12014 from: http://www.accountabilityindia.in/article/working-paper/789-enhancing-accountabilitypublic-service-delivery-through-social-audits-cas

Subha, Sri B., N Sarojini, and R Khanna. 2012. "An investigation of maternal deaths following public protests in a tribal district of Madhya Pradesh, central India," Reprod Health Matters (39):11-20.

Sundet, Geir. 2008. "Following the Money: Do Public Expenditure Tracking Surveys Matter?,” U4 Issue 8, Bergen: U4 Anti-Corruption Resource Centre, Christian Michelsen Institute.

Tembo, Fletcher. 2013. "Citizen voice and state accountability: towards theories of change that embrace contextual dynamics," Working Paper 343. London: Overseas Development Institute. Accessed on July 12014 from: http://www.odi.org/sites/odi.org.uk/files/odiassets/publications-opinion-files/7557.pdf

Tisné, M. 2010. “Transparency, Participation and Accountability: Definitions,”' Unpublished. Background Note for Transparency and Accountability Initiative.

UNFPA. 1994. "Report of the International Conference on Population and Development," New York: United Nations. Accessed on July 12014 from: http://www.unfpa.org/public/home/publications/pid/1973

United Nations. 2012. “Global Strategy for Women's and Children's Health,” Every Woman Every Child Initiative. Accessed on June 302014 from: www.everywomaneverychild.org/images/content/files/global_strategy/full/20100914_gswc h_en.pdf

UNCoLSC. 2014. "UN Commission on Life-Saving Commodities: Recommendations," Every Woman Every Child Initiative. UN Commission on Life-Saving Commodities, United Nations Foundation. Accessed on June 302014 from: http://www.everywomaneverychild.org/resources/un-commission-on-life-savingcommodities

USAID. 2013. Advancing Country Ownership: Civil Society's Role in Sustaining Public Health. Meeting Report.

USAID, PEFPAR, Health Policy Project, amFAR, Planned Parenthood Global and IPPF. 2013. Advancing Country Ownership: Civil Society's Role in Sustaining Public Health. Meeting Report. Washington, DC: Futures Group, Health Policy Project. 
Vogel, Isabel. 2012. "Review of the use of 'Theory of Change' in international development," London: DFID.

WHO. 2014. "Ensuring human rights in the provision of contraceptive information and services: Guidance and recommendations," Geneva: World Health Organization.

World Bank. 2014. Website: Social Accountability Sourcebook. World Bank: Participation and Civic Engagement Group. Accessed on July 12014 from: http://www.worldbank.org/socialaccountability_sourcebook/essd9.swf

World Bank. 2004. "World Development Report 2004: Making Services Work for Poor People," Washington, DC: World Bank. 


\section{Appendix 1: Types of Social Accountability Interventions}

\begin{tabular}{|c|c|c|}
\hline Type of Intervention & Aims & References \\
\hline $\begin{array}{l}\text { Participatory Budgeting allows } \\
\text { citizens direct participation in all } \\
\text { phases of the budget cycle: } \\
\text { formulation, decision making, and } \\
\text { monitoring of budget execution } \\
\text { (World Bank 2014). }\end{array}$ & $\begin{array}{l}\text { - Bring citizens' voices into the budgeting } \\
\text { - } \text { Inocess } \\
\text { - of budget constraints } \\
\text { - Improve targeting of public spending } \\
\text { - Reduce corruption } \\
\text { - Illuminate resource flows, leakages, } \\
\text { blockages, and delays } \\
\text { - Highlight gaps in delivery of funds } \\
\text { locally }\end{array}$ & $\begin{array}{l}\text { Goldfrank (2006) } \\
\text { Reinikka and } \\
\text { Svensson (2011) } \\
\text { Overy (2010) } \\
\text { Ringold et al. (2012) }\end{array}$ \\
\hline $\begin{array}{l}\text { Public Expenditure Tracking } \\
\text { involves civil society in monitoring } \\
\text { budget execution by means of } \\
\text { tracking flows of public resources } \\
\text { for the provision of public services } \\
\text { and goods. }\end{array}$ & $\begin{array}{l}\text { - Fight corruption by uncovering leakages } \\
\text { of funds or goods in the system between } \\
\text { the source and the destination } \\
\text { - Detect problems in service delivery in } \\
\text { the form of staff absenteeism or ghost } \\
\text { workers } \\
\text { - Improve the efficiency of budget } \\
\text { execution }\end{array}$ & $\begin{array}{l}\text { Reinikka and } \\
\text { Svensson (2011) } \\
\text { Gauthier (2006) } \\
\text { Sundet (2008) } \\
\text { Ringold et al. (2012) }\end{array}$ \\
\hline $\begin{array}{l}\text { Citizen Report cards are } \\
\text { participatory surveys that solicit user } \\
\text { feedback on the performance of } \\
\text { public services (World Bank 2014). }\end{array}$ & $\begin{array}{l}\text { Improve quality, accessibility, and } \\
\text { relevance of service delivery and public } \\
\text { works } \\
\text { - Reduce leakages and corruption }\end{array}$ & $\begin{array}{l}\text { Ravindra (2004) } \\
\text { Ringold et al. (2012) }\end{array}$ \\
\hline $\begin{array}{l}\text { Social Audits engage citizens, users } \\
\text { of services, or civil society } \\
\text { organizations in collecting and } \\
\text { publicly sharing information on } \\
\text { available resources for service } \\
\text { delivery and public works. }\end{array}$ & $\begin{array}{l}\text { - Improve quality, accessibility, and } \\
\text { relevance of service delivery and public } \\
\text { works } \\
\text { - Reduce leakages and corruption }\end{array}$ & $\begin{array}{l}\text { Pandey et al. (2008) } \\
\text { Duggal (2005) } \\
\text { Singh et al. (2010) } \\
\text { Ringold et al. (2012) }\end{array}$ \\
\hline $\begin{array}{l}\text { Community Scorecards combine } \\
\text { social audits and citizen report } \\
\text { cards, compiling information from } \\
\text { users and service providers about a } \\
\text { particular service. Data are } \\
\text { reviewed by all to allow for } \\
\text { immediate feedback and } \\
\text { development of an action plan } \\
\text { (CARE 2012). }\end{array}$ & $\begin{array}{l}\text { - Improve quality, accessibility, and } \\
\text { relevance of service delivery and public } \\
\text { works } \\
\text { - Reduce leakages and corruption. }\end{array}$ & $\begin{array}{l}\text { Misra et al. (2007) } \\
\text { Dufils (2010) } \\
\text { Ringold et al. (2012) }\end{array}$ \\
\hline $\begin{array}{l}\text { Citizen Charters articulate } \\
\text { guidelines on the client and provider } \\
\text { relationship, providing standards a } \\
\text { client can expect and demand. }\end{array}$ & $\begin{array}{l}\text { - Raise awareness about service standards } \\
\text { and client entitlements } \\
\text { - Define and disseminate the expectations } \\
\text { and standards that the providers agree to } \\
\text { uphold } \\
\text { - Ideally describe how to lodge a } \\
\text { complaint }\end{array}$ & \\
\hline
\end{tabular}




\begin{tabular}{|c|c|c|}
\hline Type of Intervention & Aims & References \\
\hline $\begin{array}{l}\text { Health Committees involve civil } \\
\text { society and government working } \\
\text { together through an institutionalized } \\
\text { oversight body to improve } \\
\text { effectiveness of the health system. }\end{array}$ & $\begin{array}{l}\text { Ensure the active participation of the } \\
\text { community in decision making } \\
\text { - Ensure wider information and } \\
\text { consultations with the community. }\end{array}$ & $\begin{array}{l}\text { Jacobs et al. (2007) } \\
\text { Lowenson et al. } \\
\text { (2004) } \\
\text { Iwami and Petchey } \\
\text { (2002) }\end{array}$ \\
\hline $\begin{array}{l}\text { Information sharing/campaigns } \\
\text { are efforts to inform citizens and } \\
\text { duty bearers about citizens' rights to } \\
\text { services, quality standards, and } \\
\text { provider performance. }\end{array}$ & $\begin{array}{l}\text { Increase awareness of services and } \\
\text { benefits, performance of service } \\
\text { providers } \\
\text { - Tackle corruption and fraud. }\end{array}$ & $\begin{array}{l}\text { Pandey et al. (2008) } \\
\text { Banerjee et al. } \\
\text { (2010) } \\
\text { Khemani (2008) } \\
\text { Jenkins (2007) } \\
\text { Ringold et al. (2012) }\end{array}$ \\
\hline $\begin{array}{l}\text { Complaint Mechanisms are } \\
\text { formal channels to express } \\
\text { dissatisfaction with a service and } \\
\text { demand redress. }\end{array}$ & $\begin{array}{l}\text { - Provide remedy for individuals that have } \\
\text { been failed or abused when engaging } \\
\text { with a public sector services } \\
\text { - Incentivize public officials and providers } \\
\text { to change behavior and enforce changes. }\end{array}$ & $\begin{array}{l}\text { Caseley (2003) } \\
\text { Maru (2010) } \\
\text { Ringold et al. (2012) }\end{array}$ \\
\hline
\end{tabular}




\section{Appendix 2: Overview of the Enabling Factors for Successful Social Accountability}

\begin{tabular}{|c|c|c|c|c|c|c|c|c|c|c|c|}
\hline KEY ENABLING FACTORS & 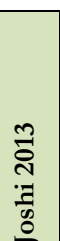 & 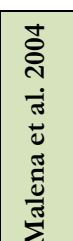 & 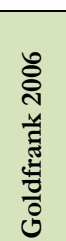 & 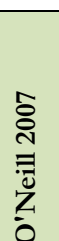 & 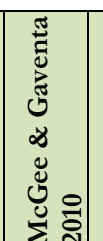 & चี & 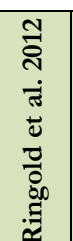 & 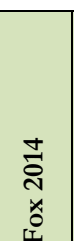 & 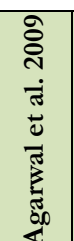 & 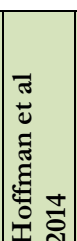 & ప్ \\
\hline $\begin{array}{l}\text { Political context - unspecified but refers to the political and legal environment for accountability - } \\
\text { freedom of information, legal protection for citizen participation, a free press, among others }\end{array}$ & & & & 1 & & 1 & & & & 1 & 3 \\
\hline $\begin{array}{l}\text { Citizens have access to information and know their entitlements, have the ability to access } \\
\text { information about a specific commitment and services as well as the processes by which } \\
\text { decision are made. This can be generally thought of as transparency. }\end{array}$ & 1 & 1 & & & 1 & & 1 & & & 1 & 5 \\
\hline $\begin{array}{l}\text { Service providers/officials/politicians have the capacity, in terms of staff, resources and } \\
\text { authority, to respond to citizens' request. }\end{array}$ & 1 & 1 & 1 & 1 & & & & & & & 4 \\
\hline $\begin{array}{l}\text { Political will/receptiveness of service providers/officials/politicians to respond to citizens' request for an } \\
\text { answer or solution to identified problem. }\end{array}$ & & & 1 & 1 & & & & & & & 2 \\
\hline $\begin{array}{l}\text { Incentives/sanctions on the party of the state force the services provider/official/politician to } \\
\text { respond and act upon request from citizens. }\end{array}$ & 1 & & & & 1 & 1 & 1 & 1 & & & 5 \\
\hline $\begin{array}{l}\text { Social Accountability activities trigger official accountability mechanisms that are associated with formal } \\
\text { incentives and sanctions (e.g. investigations and impose formal sanctions). }\end{array}$ & 1 & & & & & & & 1 & & & 2 \\
\hline $\begin{array}{l}\text { Accountability activities combine a supply (service providers' capacity and receptiveness to respond) and } \\
\text { a demand side (access and use of information) approach. }\end{array}$ & 1 & & & & & & & & & 1 & 2 \\
\hline
\end{tabular}




\begin{tabular}{|c|c|c|c|c|c|c|c|c|c|c|c|}
\hline KEY ENABLING FACTORS & 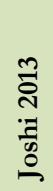 & 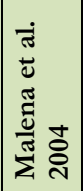 & 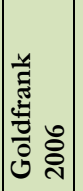 & 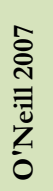 & 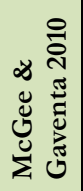 & 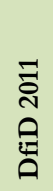 & 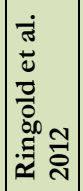 & 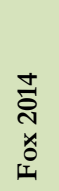 & 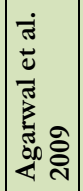 & 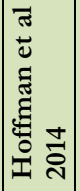 & 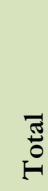 \\
\hline $\begin{array}{l}\text { Accountability initiatives build on existing social mobilization and efforts already undertaken, building on } \\
\text { existing experience and expertise. }\end{array}$ & 1 & & & & & 1 & & & & 1 & 3 \\
\hline $\begin{array}{l}\text { Social Accountability efforts use global influences (such as partners, resources, norms) to influence local } \\
\text { power relationships. }\end{array}$ & 1 & & & & & & & & & & 1 \\
\hline $\begin{array}{l}\text { There is an active independent media that can spread news and public information as well as inform } \\
\text { citizens and monitor the government's performance. }\end{array}$ & & & & & 1 & & 1 & & & & 2 \\
\hline $\begin{array}{l}\text { There are existing institutionalized mechanisms for holding service providers/officials/politicians to } \\
\text { account (such as health committees). }\end{array}$ & & 1 & & & 1 & & & & & & 2 \\
\hline There are sufficient resources to adequately support accountability work. & & & 1 & & & & & & & & 1 \\
\hline $\begin{array}{l}\text { There are actively supportive, credible and reputable personalities in higher status positions to champion } \\
\text { the request with officials. }\end{array}$ & & & & & 1 & 1 & & & & & 2 \\
\hline $\begin{array}{l}\text { "Infomediaries" (see McGee and Gaventa 2011) - individuals that can help translate accountability data } \\
\text { into formats that will resonate with decision-makers at the right opportunity. }\end{array}$ & & & & & 1 & 1 & 1 & & & & 3 \\
\hline $\begin{array}{l}\text { Accountability efforts are linked with other strategies (such as advocacy, litigation, elections etc). For } \\
\text { example linking vertical and horizontal accountability in the role of elections and parliamentarians. }\end{array}$ & & & & & 1 & & & 1 & & 1 & 3 \\
\hline $\begin{array}{l}\text { Citizens are engaged in 'upstream' actions (development of policy and regulation) and 'downstream' } \\
\text { actions (accountability efforts to ensure the implementation of said policy) }\end{array}$ & & & & & 1 & & & & & & 1 \\
\hline Accountability efforts provide concrete solutions to identified problem. & & & & & & & 1 & 1 & & 1 & 3 \\
\hline Involvement of marginalized populations & & & & & & & & & & 1 & 1 \\
\hline
\end{tabular}




\section{Appendix 3: Social Accountability Interventions in FP/RH Programming}

\begin{tabular}{|c|c|c|c|c|}
\hline Paper & $\begin{array}{l}\text { Type of } \\
\text { Accountability } \\
\text { Mechanism }\end{array}$ & Countries & Reported Results & Lessons Learned \\
\hline $\begin{array}{l}\text { Brucker et al. } \\
2011\end{array}$ & $\begin{array}{l}\text { Information } \\
\text { sharing and } \\
\text { campaigns }\end{array}$ & $\begin{array}{l}\text { Uganda, } \\
\text { Kenya, and } \\
\text { Tanzania }\end{array}$ & $\begin{array}{l}\text { - Skills of CSOs built to gather and } \\
\text { present budget data: } 8,920 \text { CSOs } \\
\text { and } 552 \text { decision-makers reached. } \\
\text { - Changes in budget allocation in } \\
\text { Tanzania and in staffing in Kenya } \\
\text { - Local government included health } \\
\text { consultations in their work plans }\end{array}$ & $\begin{array}{l}\text { - Need to understand the different types of decentralization and } \\
\text { the implications for the capacity of providers/officials to } \\
\text { respond } \\
\text { - Access to data was poor and fragmented } \\
\text { - Asymmetries between users and services providers related to } \\
\text { information, expertise } \\
\text { - With decentralization, there is less capacity at lower levels to } \\
\text { do participatory processes } \\
\text { - Get official validation of findings from parliament or ministers } \\
\text { - Invest in ensuring community buy-in } \\
\text { - Must build rapport with officials to get information } \\
\text { - Have meetings with all parties prior to interface meetings }\end{array}$ \\
\hline CARE 2012 & $\begin{array}{l}\text { Community } \\
\text { Scorecards }\end{array}$ & Global & $\begin{array}{l}\text { - Client charters for maternal rights in } \\
\text { Quechan (Peru) increased rates and } \\
\text { timeliness of health seeking } \\
\text { behavior and decreased maternal } \\
\text { deaths over four years } \\
\text { - CSOs can develop capacity to } \\
\text { monitor and report the quality of } \\
\text { health services via 'social monitors,' } \\
\text { interview clients and report to } \\
\text { providers and ombudsman } \\
\text { Increased number of birth in } \\
\text { facilities by 33\%. }\end{array}$ & $\begin{array}{l}\text { - Governance models are dependent on local context } \\
\text { Power differentials between provider and user important - } \\
\text { economers tend to be more educated, and have higher socio- } \\
\text { ectatus }\end{array}$ \\
\hline
\end{tabular}




\begin{tabular}{|c|c|c|c|c|}
\hline Paper & $\begin{array}{l}\text { Type of } \\
\text { Accountability } \\
\text { Mechanism }\end{array}$ & Countries & Reported Results & Lessons Learned \\
\hline CARE 2011 & $\begin{array}{l}\text { Community } \\
\text { scorecards }\end{array}$ & Tanzania & $\begin{array}{l}\text { Self-reported changes: (i) increased } \\
\text { awareness of need to involve women } \\
\text { in decision-making; (ii) ability of } \\
\text { women to speak to leaders and in } \\
\text { public, (iii) positive health seeking } \\
\text { behavior; (iv) more knowledge about } \\
\text { health system and about local } \\
\text { planning and budgeting, (v) perceived } \\
\text { less bribery, and (vi) perceived } \\
\text { improvement in mutual sensitivity } \\
\text { between providers and users. }\end{array}$ & $\begin{array}{l}\text { - Not able to implement commitments made in the process } \\
\text { - Problems persist, such as low quality services, bribes, informal } \\
\text { payments, abuse, unskilled workers, and queues. } \\
\text { - CSC/accountability can't solve systemic health service problems } \\
\text { - Formalized stakeholders analysis helps to analyze real decision } \\
\text { makers } \\
\text { - Time activities with local planning processes } \\
\text { - Success builds on success - start with 'quick wins' } \\
\text { - Deal with actual objective problems, not perceived problems. } \\
\text { - Accountability needs to happen in a 'safe space' that is free } \\
\text { from fear of reprisal }\end{array}$ \\
\hline $\begin{array}{l}\text { Corrêa et al. } \\
2005\end{array}$ & $\begin{array}{l}\text { Health } \\
\text { Committees }\end{array}$ & Global & $\begin{array}{l}\text { Improved health outcomes, but } \\
\text { unclear if it was due to health } \\
\text { committees or legalization of } \\
\text { universal health coverage }\end{array}$ & $\begin{array}{l}\text { - Decentralization not accompanied by devolution of power for } \\
\text { allocation of funds } \\
\text { - Variability in measurements }\end{array}$ \\
\hline $\begin{array}{l}\text { Goicolea et al. } \\
2008\end{array}$ & $\begin{array}{l}\text { Citizen report } \\
\text { cards }\end{array}$ & Ecuador & $\begin{array}{l}\text { Discrepancy between locally } \\
\text { generated and officially generated } \\
\text { data }\end{array}$ & $\begin{array}{l}\text { It is necessary to disaggregate data by residence and age to } \\
\text { identify real disparities }\end{array}$ \\
\hline $\begin{array}{l}\text { Gryboski et } \\
\text { al. } 2006\end{array}$ & $\begin{array}{l}\text { Community } \\
\text { scorecards }\end{array}$ & Nepal & $\begin{array}{l}\text { - Increased women seeking antenatal } \\
\text { care for first pregnancy } \\
\text { - Mixed results for other outcomes } \\
\text { such as contraceptive use. } \\
\text { - Notable outcomes for education } \\
\text { such as school attendance and } \\
\text { knowledge. }\end{array}$ & $\begin{array}{l}\text { Difference of engagement in rural and urban areas - less sense } \\
\text { of community in urban areas and less spare time to participate } \\
\text { in urban areas }\end{array}$ \\
\hline
\end{tabular}




\begin{tabular}{|c|c|c|c|c|}
\hline Paper & $\begin{array}{l}\text { Type of } \\
\text { Accountability } \\
\text { Mechanism }\end{array}$ & Countries & Reported Results & Lessons Learned \\
\hline $\begin{array}{l}\text { Health Policy } \\
\text { Initiative-Task } \\
\text { Order I (HPI) } \\
2010\end{array}$ & Social Audit & Global & $\begin{array}{l}\text { - In Tanzania, an increase in number of } \\
\text { skilled medical personnel at facilities - a } \\
33 \% \text { increase in staffing level within } 5 \\
\text { months at } 24 \text { facilities } \\
\text { - In India, policy tracking for payments } \\
\text { of facility delivery } \\
\text { - Increase in ante natal care } \\
\text { - Increase in equipment }\end{array}$ & $\begin{array}{l}\text { - Governments can take a long time to fulfil commitment due } \\
\text { to resource constraints } \\
\text { - Need to have short term and long term policy } \\
\text { recommendations - recognizing the need for intermediary } \\
\text { steps } \\
\text { - Limited resources limit the scope and the breadth of national } \\
\text { campaigns } \\
\text { - Struggle to get accurate and current information, this } \\
\text { information can be sensitive as it exposes weakness } \\
\text { - Hard to ensure grassroots involvement }\end{array}$ \\
\hline IPPF 2012 & $\begin{array}{l}\text { Public } \\
\text { expenditure } \\
\text { tracking }\end{array}$ & $\begin{array}{l}\text { Peru, } \\
\text { Mexico, } \\
\text { Bolivia, } \\
\text { Panama, } \\
\text { Dominican } \\
\text { Republic }\end{array}$ & $\begin{array}{l}\text { - Mexico: USD } 7.8 \text { million for state level } \\
\text { implementation of adolescent SRHR } \\
\text { policy in } 2011 \text { with an additional USD } \\
15.6 \text { million in 2013. First budget line } \\
\text { for adolescent SRHR. } \\
\text { - Creation of civic spaces (citizen } \\
\text { councils) in Peru and a municipal } \\
\text { ordinance in El Alto, Bolivia. } \\
\text { - Establishment of } 3 \text { state run youth } \\
\text { friendly health centers in Bolivia. }\end{array}$ & $\begin{array}{l}\text { - Accountability more difficult in countries without a strong } \\
\text { tradition of civic-state engagement (e.g. Panama and DR) } \\
\text { - Need to work at all levels of government because they are } \\
\text { interrelated. }\end{array}$ \\
\hline $\begin{array}{l}\text { Malajovich et } \\
\text { al. } 2012\end{array}$ & $\begin{array}{l}\text { Public } \\
\text { expenditure } \\
\text { tracking }\end{array}$ & $\begin{array}{l}\text { Peru, } \\
\text { Mexico, } \\
\text { Bolivia, } \\
\text { Panama, } \\
\text { Dominican } \\
\text { Republic }\end{array}$ & $\begin{array}{l}\text { Peru was the only place where } \\
\text { information was available; elsewhere it } \\
\text { depended on the level of transparency } \\
\text { and government data collection system. } \\
\text { Gaps in information and in access to it. }\end{array}$ & $\begin{array}{l}\text { - No centralized information - it was often spread between } \\
\text { different departments and sections of same department or at } \\
\text { district or hospital level. } \\
\text { - Funds often decentralized but not reported back centrally for } \\
\text { monitoring. }\end{array}$ \\
\hline $\begin{array}{l}\text { Papp et al. } \\
2012\end{array}$ & $\begin{array}{l}\text { Information } \\
\text { sharing and } \\
\text { campaigns }\end{array}$ & India & $\begin{array}{l}\text { - No reporting of results - improvement } \\
\text { in health outcomes or service uptake. } \\
\text { Hard to distinguish whether changes } \\
\text { due to the roll-out of the government } \\
\text { policies (NRHM. JYS etc.) or to public } \\
\text { hearings }\end{array}$ & $\begin{array}{l}\text { - Need to change mindset of providers and policy makers } \\
\text { - Need to use external levers of change } \\
\text { - Accountability must be system-led and system-supported to } \\
\text { be meaningful and sustainable }\end{array}$ \\
\hline
\end{tabular}




\begin{tabular}{|c|c|c|c|c|}
\hline Paper & $\begin{array}{l}\text { Type of } \\
\text { Accountability } \\
\text { Mechanism }\end{array}$ & Countries & Reported Results & Lessons Learned \\
\hline Parkes 2001 & $\begin{array}{l}\text { Health } \\
\text { Committees }\end{array}$ & Ghana & $\begin{array}{l}\text { - } \quad \text { Donation of office space } \\
\text { - } 5 \text { million Cedis to HIV/AIDS } \\
\text { awareness program }\end{array}$ & $\begin{array}{l}\text { - } \quad \text { Decentralization not completed. } \\
\text { - } \quad \text { Build rapport with district assemblies - are indispensable } \\
\text { - } \quad \text { Learn and make transparent decision-making process. }\end{array}$ \\
\hline $\begin{array}{l}\text { Pathfinder } \\
\text { International. } \\
2013\end{array}$ & $\begin{array}{l}\text { Citizen Report } \\
\text { Cards }\end{array}$ & Tanzania & $\begin{array}{l}\text { 88\% of responders used services; } \\
\text { none used CBD agents, but used } \\
\text { pharmacy and drug stores instead } \\
\text { because services were friendlier. }\end{array}$ & \\
\hline $\begin{array}{l}\text { Saha et al. } \\
2013\end{array}$ & $\begin{array}{l}\text { Health } \\
\text { committees }\end{array}$ & India & $\begin{array}{l}\text { - Women in villages with } \\
\text { committees } 19 \% \text { more likely to deliver } \\
\text { in an institution and } 8 \% \text { to feed new- } \\
\text { born colostrum and use FP. }\end{array}$ & $\begin{array}{l}\text { - Social capital initiatives empower communities and } \\
\text { positively influence individual and community level choices, } \\
\text { but have limited impact on their own. They must be } \\
\text { embedded within complementary health programs like the } \\
\text { NRHM. }\end{array}$ \\
\hline $\begin{array}{l}\text { Shiffman. } \\
2012\end{array}$ & $\begin{array}{l}\text { Health } \\
\text { committees }\end{array}$ & Indonesia & $\begin{array}{l}\text { - Increase in contraceptive prevalence } \\
\text { rate } \\
\text { - Decline in fertility }\end{array}$ & $\begin{array}{l}\text { - } \quad \text { Both supply and demand factors important } \\
\text { - State is not unified or monolithic - must interact with } \\
\text { idiosyncratic people to implement change. } \\
\text { - There is a complex interplay between state and social forces. }\end{array}$ \\
\hline $\begin{array}{l}\text { Subha et al. } \\
2012\end{array}$ & Social Audit & India & $\begin{array}{l}\text { - Identified gaps: i) policies are not } \\
\text { leading to better health outcomes; (ii) } \\
\text { need transport for referrals; and (iii) } \\
\text { introduction of cash incentives needs } \\
\text { to be matched by improvements in } \\
\text { infrastructure. } \\
\text { - Created a set of recommendations } \\
\text { related to the management of } \\
\text { information, a reporting system, } \\
\text { district level grievance procedures } \\
\text { with an immediate response system }\end{array}$ & $\begin{array}{l}\text { Power dimensions of accountability - people in lower social } \\
\text { positions cannot hold providers to account. }\end{array}$ \\
\hline
\end{tabular}


Working Paper 37 
The Evidence Project

Population Council

4301 Connecticut Avenue, NW, Suite 280

Washington, DC 20008 USA

Tel : +1 2022379400

Email : evidenceproject@popcouncil.org

evidenceproject.popcouncil.org 